\title{
Incorporating Financial Accounting Research Into The Accounting Curriculum
}

Bill D. Jarnagin, (E-mail: bill.jarnagin@wichita.edu), Wichita State University

LuAnn Bean, Florida Institute of Technology

Lou X. Orchard, Wichita State University

\begin{abstract}
The purpose of this paper is to describe a process of integrating the use of accounting research into the existing financial accounting curriculum in an effort to meet CPA exam research requirements as well as to improve critical thinking, written and oral communication skills, documentation and support, and analysis.
\end{abstract}

\section{INTRODUCTION}

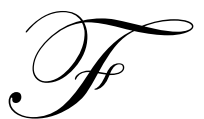

or some time now, both accounting scholars and practitioners have been calling for less classroom emphasis on memorization, and more emphasis on teaching students how to learn and find answers (e.g., Esmond-Kiger and Kirch, 2003; Albrecht and Sack 2000, pgs. 63-66; Accounting Education Change Commission 1990, Appendix A). ${ }^{1}$ At present, many financial accounting classes use a lecture and problemsolving format, especially in undergraduate courses such as intermediate and advanced accounting. The typical approach involves coverage of rules and procedures related to specific topics such as inventory, bonds, leases, etc., followed by assigned problems or cases that relate to specific topic issues or textbook chapters. Very little time, if any, is spent on actually researching financial accounting issues; supporting and documenting conclusions about the application of generally accepted accounting principles (GAAP) to specific accounting problems; conveying information to interested parties; and determining the impact of the conclusions for both external reporting and internal decision making. In addition, little time is spent on understanding the GAAP implications that may occur outside the context of narrowly defined problems.

The teaching approach described above does not prepare the students for the financial accounting research requirements of the CPA exam nor does it expose them to the complexities of decision-making and identification of relevant accounting issues that face professional accountants every day. Subsequently, students are ill-prepared when confronted with unstructured accounting issues or problems that are different than what was presented in the textbook. The result is that they may not know how to start to research the accounting problem or where to begin to search for a potential solution.

\section{PROCESS}

In order to help accounting students develop accounting research skills and foster a clear understanding of the learning process as well as discover meaning in the accounting curriculum, we suggest an integrated seven-step process. This process provides structure to the relatively unstructured task of diagnosing financial accounting problems through publications defined by the hierarchy of generally accepted accounting principles (GAAP). We propose that these steps provide a basis for a process that can be used by accounting decision makers to "frame" research problems. The seven steps in this process are:

\footnotetext{
${ }^{1}$ For example, the Accounting Education Change Commission (1990) states in Appendix A, "The process of learning should focus on developing the ability to identify problems and opportunities, search out the desired information, analyze and interpret the information, and reach a well reasoned conclusion".
} 
1. Discussion of the rule-making bodies in the private sector and the impact of the Securities and Exchange

Commission (SEC) on standard setting

2. Discussion of GAAP and the GAAP Hierarchy.

3. Discussion and demonstration of accounting databases

4. Discussion of the research process

5. Discussion of CPA exam research requirements

6. $\quad$ Review and discussion of sample case(s)

7. Review and discussion of assigned case(s)

Each of the seven steps is discussed in detail below. From an implementation standpoint, we propose that Steps $1-5$ are best covered in the first class meeting. This promotes the active learning opportunities of the course and also allows sufficient time for coverage of other introductory material as well.

\section{Step 1: Discussion of Rule Making Bodies}

Students are provided with a discussion of the organizations designated as rule-making bodies in the private sector. The discussion, which is provided below in an abbreviated format, includes the purpose of the organizations, the different rule-making bodies, and publications of each body:

The purpose of the private rule-making body is to develop accounting principles used in the preparation of financial information included in annual reports for direct and indirect users. Since 1938, there have been three different organizations that served in this capacity. These organizations are (1) the Committee on Accounting Procedure (CAP) of the AICPA, (2) the Accounting Principles Board (APB), and (3) the Financial Accounting Standards Board (FASB). Chart 1 illustrates the rule-making bodies and shows the publications of each organization.

The first organization to serve as the private sector rule-making body, the Committee on Accounting Procedure, issued accounting principles designated as Accounting Research Bulletins (ARBs). Many of the ARBs are still in effect today, and serve as accounting principles for many accounting issues. The second body, the APB, issued Accounting Principles Board Opinions (APBs), APB Statements, and American Institute of Certified Public Accountants (AICPA) unofficial interpretations. The FASB, which is the currently operating third organization, issues FASB Statements, FASB Interpretations, FASB Technical Bulletins, FASB Staff Positions, FASB Concept Statements, and consensus abstracts issued by its Emerging Issues Task Force (EITF), regarding the timely identification and review of narrow applications or emerging accounting issues.

Additional discussion focuses on the purpose of each of the different kinds of publications, the number of publications from each organization, and the current FASB due process procedure, which results in the development and issuance of Board publications. It is also noted in the discussion that the Securities and Exchange Commission (SEC) has the power under the Securities and Exchange Act of 1934 to develop accounting principles. Despite this power, however, the SEC has recognized the FASB as the designated organization to develop accounting principles for the preparation of financial reports. Recent developments or significant legislative changes to financial practice such as the Sarbanes Oxley Act are also discussed, with emphasis on how these regulation changes affect financial accounting and reporting requirements.

\section{Step 2: Discussion of GAAP And GAAP Hierarchy}

In addition to the discussion of the private sector rule-making bodies, the initial class session includes a discussion of generally accepted accounting principles and the GAAP hierarchy. The class discussion includes a review of all publications in each hierarchical level and a summary of this information is provided below.

A generally accepted accounting principle is one that has substantial authoritative support. Publications voted on and issued by the private rule-making body (Step 1) have, by definition, substantial authoritative support and therefore represent the highest level of GAAP. However, not all publications issued by the private organizations are voted on by the designated Board and therefore not all of the publications represent the highest level of GAAP. In addition, 
accounting principles issued by the private sector organizations do not represent a comprehensive list of accounting principles that cover all possible accounting issues. Therefore, accounting principles from other sources must be used in the preparation of financial reports. As a result, the AICPA issued Statement of Auditing Standards (SAS) No. 69 specifying the GAAP hierarchy, which indicates the level of substantial authoritative support given to each category of possible accounting principles. Chart 2, which illustrates the GAAP hierarchy and shows the different levels of authoritative support, is useful in the research process. Notice that the Chart shows five different levels of authoritative support, with level 1 denoting accounting principles with the highest level of authoritative support, while level 5 shows principles with the lowest level of support.

If conflicting principles at different levels arise when researching an accounting issue, the highest level of support (or lowest numeric level) has priority standing (i.e., accounting principles in level 1 have more substantial authority support than principles in level 2, etc.). The discussion should include emphasis on the new exposure draft released by the FASB entitled "The Hierarchy of Generally Accepted Accounting Principles." The proposed statement specifies that the new GAAP hierarchy does not change current practice, but will carry forward the SAS No. 69 categorization by document type as specified in Paragraph .10 of SAS No. 69. In addition, Level 1 GAAP will increase to include all accounting principles subjected to scrutiny by FASB due process, FASB Staff Positions, and implementation issues of FASB Statement No. 133.

\section{Step 3: Discussion and Demonstration of Accounting Data Bases}

Once students are equipped with an understanding of private rule-making bodies and generally accepted accounting principles, accounting research databases are discussed and demonstrated in preparation for applied projects. The accounting databases currently used in our class research projects are (1) Financial Accounting Research System (FARS) and (2) Lexis/Nexis/NAARS. However, other accounting databases are also available and may be used in the research process.

The content and structure of each database is discussed and explained through step-by-step handouts on how to use the database and also through hands-on demonstrations of specific accounting research issues using actual accounting problems. With the brief introduction, handout materials, and demonstration, we have found that students have little trouble, if any, in using the databases for the search process, but may experience problems in formulating an appropriate search code for a specific accounting problem.

\section{Step 4: Discussion of the Research Process}

Step 4 of the integrated financial accounting research process involves initiating discussion about eight active learning components. As an introduction to this discussion, instructors should focus on the critical importance of formulation of the accounting problem. It might be good to begin this section with the old adage that says "A problem well defined is a problem half solved." This adage emphasizes a logical definition of the problem as a precursor for a clearer understanding of what type of information to explore, collect, review, synthesize, and finally evaluate.

Each of the components of this active learning process is discussed in detail in the first class period and includes:

1. gathering all relevant information,

2. reviewing all information and formulating the accounting issue to be researched,

3. determining all accounting principles that could pertain to the accounting issue under consideration,

4. reviewing all accounting principles that could support a possible solution,

5. developing all possible solutions using the accounting principles with the greatest potential for a solution, as identified previously,

6. selecting the best solution and supportive accounting principles in accordance with the GAAP Hierarchy,

7. determining the impact of the solution on external financial statements and internal decisions, and

8. $\quad$ communicating the solution and impact in written form to all required parties. 


\section{Step 5: Discussion of CPA Exam Research Requirements}

The new research requirements for the CPA exam are discussed in detail using the Financial Accounting Research System to illustrate possible CPA exam research questions. As part of this presentation, we focus on the web-based CPA exam tutorial which showcases how accounting research proficiency will be evaluated using case study simulations ${ }^{2}$. Once the tutorial is activated, it is beneficial to have students gain a general understanding of the response tasks and general functionality required for both the Accounting and Reporting cases and the Professional Standards items. By following the Authoritative Literature link, the tutorial can supply students with an integrated understanding about how to find the appropriate accounting literature database during the exam, as well as examine the format of the questions and how the research requirements will be tested on the new on-line CPA exam.

\section{Step 6: Review And Discussion Of Sample Case}

On the first day of class, the student is provided a sample case similar to the type of cases that will be used during the semester. The student is given two weeks to review the case without a requirement of formally preparing a written response. Over that period, the instructor acts in a supervisory or mentoring capacity to help students move through the eight-step research process. Student also find the peer input of these question and answer sessions to be valuable, as well, in providing him/her with a good understanding of how to formulate the issues, develop alternative solutions, select the best solution given all the facts, and determine the impact of the solution. At the close of this two week period, the student is provided a copy of the formal solution to the sample case.

\section{Step 7: Review And Discussion Of Assigned Case}

After the example case is discussed, a separate research case is assigned as either an individual or group project. In either case, a formal written case proposal is submitted for a grade.

If an individual student project is assigned, the student's written response is turned in at the beginning of the class session. The student is asked to keep a copy of the written report to be used as a basis for discussion. The case is then reviewed in a seminar format using the eight steps described in Step 4. All students must participate by providing input for each of the steps.

When the case is assigned as a group project, each group turns in a written paper at the beginning of the class period. If there are several groups in the class, different cases are assigned so that only two groups present the same case. Each group provides an oral presentation, generally using MS Power Point, which covers each of the eight steps in the research process. All remaining students in the class have an opportunity to provide comments and ask questions about the presentations. After two groups present the same case, the instructor can provide an oral review of the case, which highlights either the correctness of the group conclusions or explains the nuances of the facts of the case and the most likely or best solution.

\section{CLASSROOM ILLUSTRATION}

To illustrate application of the research process, a case involving an aircraft manufacturer is used. This case illustrates current revenue recognition issues facing the profession. The student is told to assume that he/she has been placed in a special projects position assigned to the controller's office of the company. The facts of the case are:

You are a new employee of Aircraft Manufacturing Inc. (AMI), a 100\% owned subsidiary of Aircraft Inc., assigned to the controller's office as a special projects employee. The company expects to sell a $\$ 10,000,000$ corporate jet to Jetways, Inc. with a guaranteed resale value after 8 years. The controller is not sure about the proper accounting for the sale. A special project to determine the appropriate accounting for the anticipated sale has been assigned to you.

\footnotetext{
${ }^{2}$ The material for this demonstration can be accessed through the AICPA website or directly through the URL address of http://www.cpaexam.org.The on-line CPA exam research tutorial may be accessed by selecting the Tutorial and Sample Tests, available under the heading Preparing for the Exam.
} 
The following facts relate to the expected sale: The plane is expected to be sold on 1/1/X7 at a cash price of $\$ 10,000,000$ (cost of plane is $\$ 8,000,000$ ). At the end of 8 years, Aircraft Manufacturing guarantees that the plane's value will not be less than $\$ 3,000,000$. If the plane cannot be sold for at least $\$ 3,000,000$, Aircraft will buy the plane back for the $\$ 3,000,000$ guaranteed amount. The plane is expected to have a value of $\$ 2,000,000$ at the end of 8 years. The estimated life of the equipment is 13 years. Aircraft Manufacturing normally charges $8 \%$ annual interest on installment sales transactions and Jetways normally pays $6 \%$ interest on financed purchases. Further assume that the plane was sold to Jetways for $\$ 10,000,000$ on $1 / 1 / \mathrm{X} 7$ and Jetways resold the plane at the end of 8 years for $\$ 3,400,000$.

REQUIRED: Research the accounting issue using FARS or another appropriate accounting data base. Write a formal memo to the controller (Mary Jones) indicating the proper accounting for the facts presented above and indicate their impact on external financial statements and internal decision making. If more than one method is appropriate, recommend one method for the company and justify your position. Be sure to support your position with the proper generally accepted accounting principle(s) and indicate which level of the GAAP Hierarchy would apply to this situation. Your grade will be based on your research and writing skills.

After a careful review of all the facts, most students determine that the central accounting problem concerns when the revenue from the sale of the aircraft should be recognized. Students easily find the accounting principle (EITF No. 95-1) that applies to this type of situation. Since there are no alternative accounting principles, the student is not faced with the issue of having to make a choice between alternative standards. However, because the transaction must be accounted for as a lease, several critical thinking issues, as well as alternative decisions, must be addressed.

Since the transaction is a lease, students must research the requirements for lease accounting and understand how to classify leases as either operating, direct-financing, or sales-type leases. The following critical thinking or decision-making issues are raised in the classification issue: (1) does title actually pass in this transaction? (2) what are the lease payments, since all payments are paid at the time of the transaction? (3) what is the present value of the lease payments? (4) does the risk transfer test related to uncertainty about unreimbursable costs cause what might be a salestype lease to be classified as an operating lease? (5) how can the manufacturing company have a direct financing lease? and (6) does the form of guarantee provided by the aircraft manufacturing company require special accounting other than that indicated in EITF No. 95-1?

If the students elect an operating lease based on the facts, then EITF No. 95-1 provides some guidelines about the appropriate accounting. The students must apply the guidelines to the facts of the case to illustrate the proper accounting. The solution for this determination is presented in memo format with accompanying schedules in Exhibit 1.

On the other hand, if students determine that the facts support the accounting treatment as a sales-type lease, then only guidelines in FASB Statement No. 13 and FASB Interpretation No. 45 are available as explanations. To illustrate this choice, Exhibit 2 presents a memo and accompanying schedules for the sales-type lease. Thus, this type of practical example case is recommended to advance critical thinking processes required by future accounting professionals in the area of capital and operating lease accounting.

\section{DISCUSSION OF CASE RESULTS}

The value of this type of case is that it requires the students to combine both critical thinking process and analysis issues. Critical thinking is required because the student must recognize the main question of the case and then make certain decisions related to the issue of determining the type of lease, in conjunction with the authoritative accounting literature. In addition, the guaranteed resale value by Aircraft Manufacturing, Inc., requires a decision about whether the accounting as specified in FASB Interpretation No. 45 is applicable to the situation. Finally, decisions must be made about the impact of the selected accounting on the external financial statements and ratios, as well as internal decision-making issues.

Regardless of whether this case or a similar case is used to incorporate accounting research into the classroom, the key point is to select simulations that extend to the blurred boundaries of the accounting guidance and can lead to classroom discussion and higher order thinking. With the case we present, most of the decisions related to lease classification tests are 
straight-forward (i.e., no bargain purchase option mentioned, predictable collectibility demonstrated by a total sales price collected in advance, etc.). However, decisions about the transfer of ownership and whether uncertainties exist regarding unreimbursable costs are not clear cut. An initial review of the potential sale of the aircraft indicates that title transfers since the plane is sold for a cash price. However, the substance of the transfer should be analyzed since AMI has guaranteed a resale value for the plane. In other words, if the plane cannot be sold for that guaranteed value, AMI will buy the plane back. So, the question becomes: Has the substance of the transfer changed because of the guaranteed resale value?

This ambiguity allows a major discussion of substance over form and when title to property passes to the buyer. Since there is a guaranteed resale value, the student must then make a decision about whether the guarantee creates uncertainty about unreimbursable costs. The student could take the position that the guarantee does create uncertainty since the plane could be worthless at the end of the guaranteed resale period. If so, AMI would suffer an overall loss of $\$ 1,000,000$ (\$2,000,000 profit - \$3,000,000 guarantee). This conclusion would require that the lease be treated as an operating lease even if the student assumed that the sale resulted in a transfer of ownership. On the other hand, the student could make the case that the guarantee is no different than a guaranteed residual value in a normal lease transaction. Since AMI deals in the sale of aircraft, the company could estimate the resale value using historical data. Preference for this alternative could overcome the uncertainty issue. In any event, the point creates interesting discussions relative to uncertainties and estimates in accounting information.

The next major decision issue is whether FASB Interpretation No. 45 applies to the guaranteed resale value. If the student determines that the lease is an operating lease, Interpretation No. 45 would not apply to the guarantee. Since the lessor does not remove the asset from its financial statements when accounting for an operating lease, any guaranteed resale value would be a market guarantee of the asset that the lessor is reporting in its financial statements. Therefore, FASB Interpretation No. 45 would not be applicable to a company that guarantees its own asset.

However, if the student determined that the sale is classified as a capital lease, the asset would be removed from the financial statements of the lessor and the guarantee would be a market value guarantee of an asset in the financial statements of the lessee. In this case, the provisions of Interpretation No. 45 would be applied to the guaranteed resale transaction, and stimulate excellent classroom discussion relative to the interpretation of accounting standards.

Finally, determining the impact on the financial statements of AMI as a result of the decision made by the student about the appropriate accounting requirement can be used as a segue to a discussion about the financial statement impact of alternative accounting decisions.

\section{CONCLUSION}

This paper illustrates an effective method of integrating accounting research into the financial accounting curriculum at both the undergraduate and graduate levels. Through an active learning approach, students benefit by realizing more complex educational outcomes of analysis, application, and evaluation with respect to real life accounting problems. The approach can be used in such a way as to take very little class time and can be used with very little curricular change in the approach used to teach existing financial accounting classes. We have found that this is an excellent way of developing critical thinking skills, improving written and oral communication skills, developing documentation and analysis skills, fostering life-long learning, and providing students with information about the GAAP hierarchy and research requirements of the new CPA exam.

\section{REFERENCES}

1. Accounting Education Change Commission (1990). Position Statement Number One: Objectives of Education for Accountants, Sarasota, FL, American Accounting Association, Appendix A. http://aaahq.org/AECC/PositionsandIssues/pos1.htm\#appa

2. Albrecht, W. Steve, and Robert J. Sack (2000). Accounting Education: Charting the Course Through a Perilous Future, Sarasota, FL, American Accounting Association, pgs. 63-66. 
3. American Institute Of Certified Public Accountants (2001). AICPA Professional Standards, AU 411, SAS No. 69, The Meaning of Present Fairly in Conformity with Generally Accepted Accounting Principles, AICPA, New York.

4. Esmond-Kiger, Connie and David Kirch (2003). Implementing the Business Activity Model for Teaching Intermediate Accounting: A Recipe for Success, Management Accounting Quarterly, Vol. 4 (4), pp. 53-62.

5. Financial Accounting Standards Board. (1976). Statement of Financial Accounting Standards No. 13: Accounting for Leases, Norwalk, CT: FASB, November.

6. Financial Accounting Standards Board. (1995). EITF Abstracts No. 95-1: Revenue Recognition on Sales with a Guaranteed Minimum Resale Value, Norwalk, CT: FASB, November.

7. Financial Accounting Standards Board. (1998). Statement of Financial Accounting Standards No. 133: Accounting for Derivative Instruments and Hedging Activities, Norwalk, CT: FASB, June.

8. Financial Accounting Standards Board. (2002). FASB Interpretation No. 45: Guarantor's Accounting and Disclosure Requirements for Guarantees, Including Indirect Guarantees of Indebtedness of Others, Norwalk, CT: FASB, November.

9. Financial Accounting Standards Board. (2005). Proposed Statement of Financial Accounting Standards: The Hierarchy of Generally Accepted Accounting Principles, Norwalk, CT: FASB, April.

\section{$\underline{\text { EXHIBIT } 1}$}

Provided below is the solution to the case assuming that the transaction is accounted for as an operating lease. The appropriate generally accepted accounting principles come from GAAP Hierarchy Levels 1 and 3.

\section{E M O R A N D U M}

$\begin{array}{ll}\text { To: } & \text { Mary Jones } \\ \text { FROM: } & \text { Student Name } \\ \text { DATE: } & 1 / 1 / \mathrm{X} 7\end{array}$

SUBJECT: Accounting for revenue from the sale of aircraft with a guaranteed resale value.

Presented below are the results of the research concerning the sale of a corporate jet with a guaranteed resale value by the company. The facts of the sale are as follows:

1. The Company expects to sell a $\$ 10,000,000$ corporate jet to Jetways, Inc. on $1 / 1 / \mathrm{X} 7$ at a cash price of $\$ 10,000,000$ with a guaranteed resale value after 8 years.

2. The plane costs the Company $\$ 8,000,000$ and the Company guarantees that the plane's value will not be less than $\$ 3,000,000$ at the end of 8 years, or the plane will be repurchased by Aircraft Manufacturing.

3. The plane is expected to have a value of $\$ 2,000,000$ at the end of 8 years and the Company will have to pay Jetways the excess (if any) of the guaranteed resale value over the actual selling price at the end of 8 years.

4. The estimated life of the plane is 13 years and the plane was sold for $\$ 3,400,000$ at the end of the 8 year guaranteed period.

5. Aircraft Manufacturing Inc. normally charges $8 \%$ for installment sales and Jetways, Inc. normally pays $6 \%$ on such purchases.

\section{RECOMMENDATION:}

The sale of the corporate jet should be accounted for as a lease and classified as an operating lease, or sales-type lease $^{3}$ in accordance with the provisions of FASB Statement No. 13 (FASB Emerging Issues Task Force (EITF) Minutes 95-1)). For a lease to be classified as a sales-type lease it must meet one of criteria 1 - 4 and both criteria 5 and 6 listed below: (1) title transfers by the end of the lease term, (2) the agreement contains a bargain purchase option, (3) the lease term is $75 \%$ or more of the remaining useful life of the aircraft, (4) the present value of the lease payments is $90 \%$ or more

\footnotetext{
${ }^{3}$ A manufacturing company, such as AMI, could have a direct financing lease if the cost of manufacturing the leased item is equal to its fair value.
} 
of the fair value of the aircraft, (5) collectibility of the minimum lease payment is reasonably predictable, and (6) no uncertainties surround any unreimbursable costs or there are no unreimbursable costs (Paragraph 7 of SFAS No. 13). Since the aircraft will be sold to Jetways, Inc. for a cash payment, title to the aircraft is assumed to pass at the time of the sale and criterion 1 is met. However, criteria 2-4 are not met (See Schedule A below).

Since the agreement meets one of the first four criteria, the agreement must be checked for criteria 5 and 6 . Since criterion 6 is not met, the sale is accounted for as an operating lease. The guaranteed minimum resale value of $\$ 3,000,000$ may create significant uncertainty about the amount of revenue the Company will actually derive from the agreement. If the Company actually pays $\$ 3,000,000$ to repurchase the plane at the end of the agreement, Aircraft Manufacturing may have a loss of $\$ 1,000,000$ from the transaction $(\$ 10,000,000$ selling price $-\$ 8,000,000$ cost $-\$ 3,000,000$ resale guarantee $=$ $\$ 1,000,000)$.

The $\$ 10,000,000$ from the sale of the aircraft should be reported as a liability on $1 / 1 / \mathrm{X} 7$, and the $\$ 7,000,000$ excess of the selling price over the guaranteed resale value $(\$ 10,000,000$ price $-\$ 3,000,000)$ should be reported as revenue of $\$ 875,000$ per year (Schedule B) using a pro rata basis from the 1/1/X7 sale date until 12/31/X14, the first date the minimum guaranteed resale value can be exercised (FASB EITF Minutes 95-1). The cost of the aircraft should remain on the books of Aircraft Manufacturing until the minimum resale option is exercised and the asset should be depreciated over the 8-year option period as if the company retained ownership of the aircraft. Annual depreciation expense for the aircraft of $\$ 750,000$ (Schedule C) is computed using a straight-line method over the 8-year option period. A $\$ 2,000,000$ residual value is used in the computation since it is smaller than the guaranteed resale value. At the end of X14, the end of the option period, the equipment is sold for $\$ 3,400,000$ and the company has no obligation relative to the resale clause since the asset was sold for an amount in excess of the guaranteed resale amount. On this date, the $\$ 3,000,000$ guaranteed resale value is reported as revenue and the $\$ 3,000,000$ liability is removed. In addition, the $\$ 2,000,000$ residual value is reported as depreciation expense and the aircraft of $\$ 8,000,000$ and accumulated depreciation of $\$ 6,000,000$ are removed from the books (see Schedule D for all required journal entries). With the lease accounted for as an operating lease, FASB Interpretation No. 45 does not apply to the guaranteed resale value, since the market guarantee is for an asset retained on AMI's financial statements.

As a result of the preceding transaction, cash and current assets will increase by $\$ 10,000,000$, liabilities will increase by $\$ 10,000,000$ (current by $\$ 875,000$ and long-term by $\$ 9,125,000$ ), revenue will increase and liabilities will decrease by $\$ 875,000$ in year 1 and each year thereafter until the transaction is complete, depreciation expense will increase by $\$ 750,000$ in year 1 and each year thereafter until the transaction is complete, income will increase by $\$ 125,000$ each year, and several ratios, such as the current ratio and the debt to equity ratio will be impacted. In X14 as a result of sale of the airplane by Jetways, liabilities will decrease by $\$ 3,000,000$ and revenue will increase by $\$ 3,000,000$, depreciation expense increases by $\$ 2,000,000$, net long-term assets decrease by $\$ 2,000,000$, and income increases by $\$ 1,000,000$. Since revenue, expenses and ratios are impacted, internal decisions from the parent company may be impacted. In addition, bonuses may be impacted since revenue and income are reported over future accounting periods instead of at the time of the transfer of the plane.

If you have questions about the research please let me know.

\section{Schedule A - Criteria For Lease Classification}

\section{Criterion 1 - Transfer of Ownership}

- $\quad$ Ownership transfer by the end of the lease term since Jetways will purchase the plane with an upfront cash payment.

\section{Criterion 2 - Bargain Purchase Option}


- $\quad$ No bargain purchase option

Criterion 3 - 75\% Rule

Not Met

- 8 Years (life of agreement/13 Years (life of plane) $=61.5 \%$

Criterion 4 - 90\% Rule

Not Met

Minimum lease payment

$\$ 7,000,000$

Present value factor for an

1.000000

Annuity due ( $8 \%$ for 1 period)

$\$ 7,000,000$

Present value of minimum lease payments

$\$ 7,000,000$ present value $/ \$ 10,000,000$ fair value $=70 \%$

Criterion 5 - Collectibility Of Minimum Lease Payment

- $\quad$ Criterion 5 is met since the total sales price is collected in advance.

Criterion 6 - No Uncertainties About Unreimbursable Costs Not Met

- $\quad$ Since Aircraft Manufacturing may have to pay as much as $\$ 3,000,000$ to repurchase the plane at the end of the agreement, such a guarantee may create significant uncertainty about costs and could force the Company into a $\$ 1,000,000$ loss from the transaction $(\$ 10,000,000$ revenue - $\$ 8,000,000$ cost - $\$ 3,000,000$ guarantee).

\section{Schedule B - Computation Of Annual Revenue}

Selling price of aircraft

$\$ 10,000,000$

Minimum resale value

$3,000,000$

Revenue to recognize until resale value is exercised

$\$ 7,000,000$

Life of agreement

$\div 8$ years

Revenue recognized per accounting period

$\$ 875,000$

\section{Schedule C - Computation Of Annual Depreciation}

Aircraft cost

$\$ 8,000,000$

Expected residual value

Amount subject to depreciation

$\$ 6,000,000$

Useful life (in years)

$\$ 750, \stackrel{\div 8}{\div 000}$

Annual depreciation 


\section{Schedule D - Journal Entries}

$\underline{\text { 1/1/X7 }}$

Cash

$10,000,000$

Liability from Sale of Asset with Minimum Resale Value

$10,000,000$

12/31/X7 - 12/31/X14

Liability from Sale of Asset with Minimum Resale Value

875,000

Revenue

875,000

12/31/X7 - 12/31/X14

Depreciation Expense

750,000

Accumulated Depreciation

750,000

12/31/X14

Liability from Sale of Asset with Minimum Resale Value

$3,000,000$

Revenue

$3,000,000$

12/31/X14

Depreciation Expense

$2,000,000$

Accumulated Depreciation

$6,000,000$

Aircraft

$8,000,000$

\section{EXHIBIT 2}

Provided below is the solution to the case assuming that the transaction is accounted for as a sales-type lease. The appropriate generally accepted accounting principles come from GAAP Hierarchy Levels 1 and 3.

\section{E M O R A N D U M}

TO: $\quad$ Mary Jones

FROM: Student Name

DATE: $\quad 1 / 1 / \mathrm{X} 7$

SUBJECT: Accounting for revenue from the sale of aircraft with a guaranteed resale value.

Presented below are the results of the research concerning the sale of a corporate jet with a guaranteed resale value by the company. The facts of the sale are as follows:

1. The Company expects to sell a $\$ 10,000,000$ corporate jet to Jetways, Inc. on $1 / 1 / \mathrm{X} 7$ at a cash price of $\$ 10,000,000$ with a guaranteed resale value after 8 years.

2. The plane costs the Company $\$ 8,000,000$ and the Company guarantees that the plane's value will not be less than $\$ 3,000,000$ at the end of 8 years.

3. The plane is expected to have a value of $\$ 2,000,000$ at the end of 8 years and the Company will have to pay Jetways the excess (if any) of the guaranteed resale value over the actual selling price at the end of 8 years.

4. The estimated life of the plane is 13 years and the plane was sold for $\$ 3,400,000$ at the end of the 8 year guaranteed period.

5. Aircraft Manufacturing Inc. normally charges $8 \%$ for installment sales and Jetways, Inc. normally pays $6 \%$ on such purchases. 
RECOMMENDATION: The sale of the corporate jet should be accounted for as a lease and classified as an operating lease, or sale-type capital lease $e^{4}$ in accordance with the provisions of FASB Statement No. 13 (FASB Emerging Issues Task Force (EITF) Minutes 95-1)). For a lease to be classified as a sales-type lease, it must meet one of criteria 1 - 4 and both criteria 5 and 6 listed below: (1) title transfers at the end of the lease term, (2) the agreement contains a bargain purchase option, (3) the lease term is $75 \%$ or more of the remaining useful life of the aircraft, (4) the present value of the lease payments is $90 \%$ or more of the fair value of the aircraft, (5) collectibility of the minimum lease payment is reasonably predictable, and (6) no uncertainties surround any unreimbursable costs or there are no unreimbursable costs (Paragraph 7 of SFAS No. 13). The aircraft sale meets criteria 1, 5 and 6 (Schedule X).

Since the agreement meets at least one of the first four criteria and both criterion 5 and 6 , the lease is classified as a capital lease. Since it is apparent that the aircraft's fair value exceeds the lessor's book value at the time of sale, the capital lease is classified as a sales-type lease. The guaranteed minimum resale value of $\$ 3,000,000$ does not create a significant uncertainty about the amount of revenue the Company will actually derive from the agreement. The guaranteed resale value is no different from a guaranteed residual value for a normal lease, and company experience can be used to determine any uncertainties about unreimbursable costs. Since the sale of the plane is classified as a sales-type capital lease, the asset would be removed from the financial statements of the lessor and the guaranteed resale value of $\$ 3,000,000$ would be classified as a market value guarantee of an asset in the financial statements of the lessee and the provisions of FASB Interpretation No. 45 would be applied to the guaranteed resale transaction (Paragraph 3, FASB Interpretation No. 45 \& EITF 95-1).

On $1 / 1 / \mathrm{X} 7$, the date of the sale, $\$ 10,000,000$ in cash is reported, the present value of the minimum lease payment of $\$ 7,000,000$ (Schedule $\mathrm{X}$ ) is reported as sales, and a liability for a guaranteed resale value is recorded for $\$ 3,000,000$, the fair value of the guaranteed resale value (Paragraphs $9 \& 11$, FASB Interpretation No. 45). Cost of sales is recorded for $\$ 8,000,000$, the aircraft is removed from the books of Aircraft Manufacturing, and a loss of $\$ 1,000,000$ is reported in X7 from the sale of the aircraft (Paragraph 17 of SFAS No. 13). The $\$ 3,000,000$ liability for the guaranteed resale value is reported as sales in X14, the year the minimum resale value option is exercised, since the aircraft was sold for an amount in excess of the guaranteed resale amount (see Schedule $\mathrm{Y}$ for all required journal entries).

As a result of the preceding transaction, cash and current assets will increase by $\$ 10,000,000$, liabilities will increase by $\$ 3,000,000$, revenue will increase by $\$ 7,000,000$ in $X 7$, cost of sales will increase by $\$ 8,000,000$ in X7, loss of $\$ 1,000,000$ is recorded for $\mathrm{X} 7$, and several ratios, such as the current ratio and the debt to equity ratio will be impacted. In $\mathrm{X} 14$ as a result of sale of the airplane by Jetways, liabilities will decrease by $\$ 3,000,000$ and revenue will increase by $\$ 3,000,000$ and income will increase by $\$ 3,000,000$. Since revenue, expenses and ratios are impacted, internal decisions from the parent company may be impacted. In addition, bonuses may be impacted since revenue and income are reported over future accounting periods instead of at the time of the transfer of the plane.

If you have questions about the research please let me know.

\section{Schedule X - Criteria for Lease Classification}

Criterion 1 - Transfer of Ownership

- Ownership transfers at the end of the lease term

Criterion 2 - Bargain Purchase Option

Not Met

- $\quad$ No bargain purchase option

\footnotetext{
${ }^{4}$ A manufacturing company, such as AMI, could have a direct financing lease if the cost of manufacturing the leased item is equal to its fair value.
} 
- 8 Years (life of agreement/13 Years (life of plane) $=61.5 \%$

Criterion 4 - 90\% Rule

Not Met

- $\quad$ Minimum lease payment

$\$ 7,000,000$

Present value factor for an annuity due ( $8 \%$ for 1 period)

Present value of minimum lease payments

$\$ 7,000,000$ present value $/ \$ 10,000,000$ fair value $=70 \%$

Criterion 5 - Collectibility of Minimum Lease Payment

Met

- $\quad$ Criterion 5 is met since the total sales price is collected in advance.

Criterion 6 - No Uncertainties about Unreimbursable Costs

- $\quad$ There are no significant uncertainties regarding any unreimbursable costs. The guaranteed resale value is no different from a guaranteed residual value for a normal lease agreement and company experience could be used to determine if this creates unreimbursable costs.

\section{Schedule Y - Journal Entries}

1/1/X7

Cash

$10,000,000$

Sales

Liability from Guaranteed Resale Value

$7,000,000$

$3,000,000$

Cost Of Sales

$8,000,000$

Aircraft

$8,000,000$

12/31/X14

Liability from Guaranteed Resale Value

$3,000,000$

Sales

$3,000,000$ 


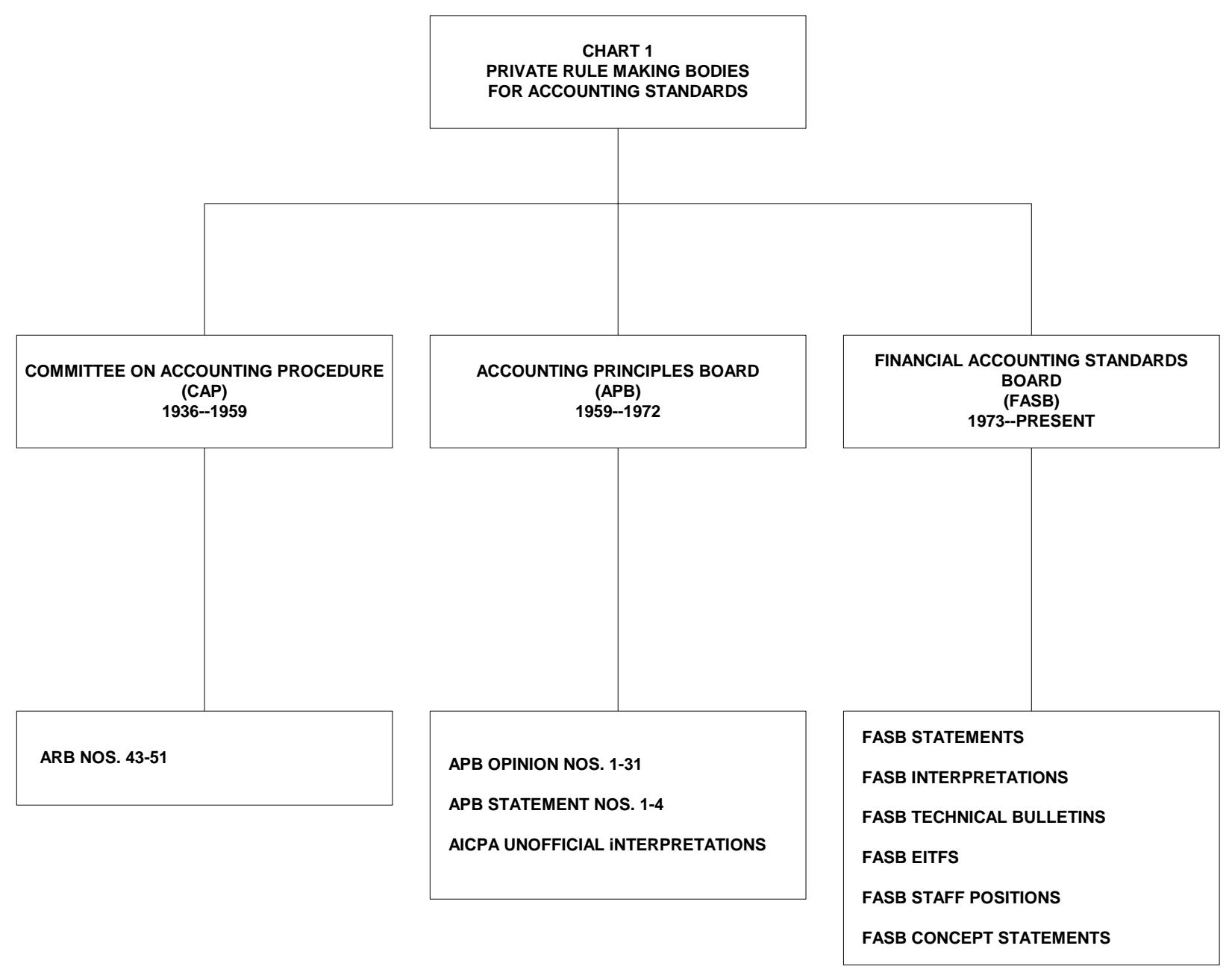




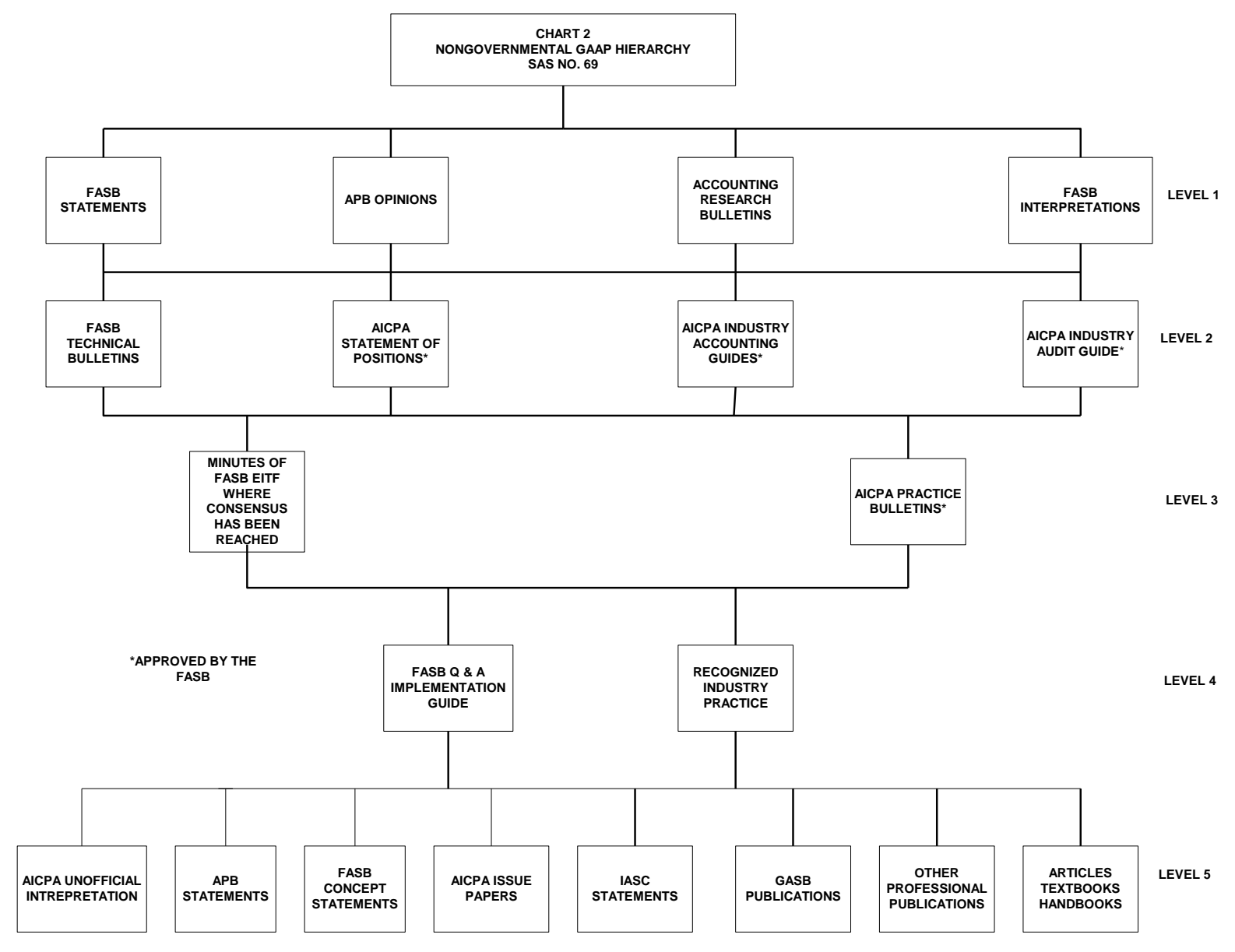

